\title{
Research on the Port Information Construction of Beijing-Tianjin-Hebei Region in China
}

\author{
Dong Xinyi, Wang Senhao, Wang Xiaofan \\ School of Information, Beijing Wuzi University, Beijing, China \\ Email address: \\ dongxinyi1991@126.com (Dong Xinyi),872533287@qq.com (Wang Senhao),835549379@qq.com (Wang Xiaofan)
}

\section{To cite this article:}

Dong Xinyi, Wang Senhao, Wang Xiaofan. Research on the Port Information Construction of Beijing-Tianjin-Hebei Region in China. International Journal of Business and Economics Research. Vol. 5, No. 4, 2016, pp. 80-84. doi: 10.11648/j.ijber.20160504.11

Received: May 23, 2016; Accepted: June 1, 2016; Published: June 23, 2016

\begin{abstract}
With deepening of Beijing-Tianjin-Hebei regional cooperation, the integration results appear constantly, port construction accounts for a large proportion in the integration of the Beijing-Tianjin-Hebei region. With the deepening of the level of opening to the outside world, in recent years, cross-border trading volume continues to rise, which provides a good room for growth for many foreign trade enterprises. There are many new bonded area and airport center appeared in Beijing-Tianjin-Hebei region, and enterprise need through these ports to do import and export business, so the development of the integration of the Beijing-Tianjin-Hebei region put forward higher requirements on the informatization construction. This paper makes a brief introduction to the current situation of Beijing Tianjin Hebei Port and the operation and information system of the logistics information platform, makes a comparative summary of the functions of electronic ports in Beijing, Tianjin and Hebei, and makes a conclusion.
\end{abstract}

Keywords: Integration, Beijing-Tianjin-Hebei Region, Electronic Port

\section{Introduction}

Along with the continuous development of the integration of the Beijing-Tianjin-Hebei region, the free trade zone, port, customs, airports and other ports are speeding up the integration process. The coordinated development of Beijing-Tianjin-Hebei makes many enterprises enjoy the benefits of the customs clearance. With the speeding up of the trade, in addition to some original port, there are many new ports appeared, such like Chaoyang port, Fengtai freight port, Beijing west railway station railway port, Beijing tianzhu free trade zone, Beijing e-town bonded area, Caofeidian bonded area, The capital international airport in the Beijing area, and Tianjin port, Tianjin east bonded harbor area, Tianjin binhai international airport in Tianjin region, and Shijiazhuang customs, Qinhuangdao port, Shijiazhuang positive definite airport in Hebei region.

Since July 1, 2014, the Beijing-Tianjin-Hebei integration process for custom clearance has been through over two years, the local customs fragmented before the integration of customs clearance. In order to promote the market integration process, Beijing, Tianjin and Hebei reached 10 consensuses on
10 items, item 4 is about port construction that promotes the coordinated development of development zones and comprehensive bonded zones. [1] Each business site can only execute the customs clearance instructions two years ago, it is difficult to cross customs clearance of goods under the same customs, and the enterprise must travel back and forth between the different customs in. After the integration of customs clearance, customs can release inbound and outbound goods in the three ports of enterprises, and enterprises can no longer use the traditional customs supervision means to handle the transit transport. Regional cooperation between ports can be seen a strategy to deal with the fierce competition between ports, in the future, there should be a kind of dynamic mutual cooperation among ports-Coopetition. [2]

Now, the goods imported from Beijing or Tianjin, and Shijiazhuang customs can release it, which greatly facilitates the operation of the company's customs clearance, shorts the time for customs clearance. With paperless office and efficiency of customs clearance, enterprises can remote control the import and export of goods through the computer, which is the benefit of the development of the port information. [3] 


\section{The Importance of Information Construction in Beijing-Tianjin-Hebei Port}

The port was initially defined by the state's coastal ports designated foreign trade, nowadays, the port has not only dealt with economic and trade exchanges, but also includes political, diplomatic, scientific and technological, cultural, tourism and immigration and other aspects. Port as an international logistics system bottleneck, compared with the general social logistics, port logistics involved in the sector more widely, such as regulation of foreign trade department, transportation management departments, units engaged in transportation, warehousing enterprises, production trade enterprises, financial institutions, and port related information is more complex, such as goods information, terminal information, information of customs clearance, inspection information. In addition to the enterprise's own internal data flow, a large number of data exchange between enterprises also need a public information platform to be completed, in order to improve the work efficiency and strengthen the cooperation and communication between enterprises, it is necessary to dredge the information flow to realize the effective connection of each link, so it is very necessary to strengthen the information construction of the port logistics [4].

Along with the rapid development of information technology today, "transnational corporation", "supply chain", "zero inventory", "third party logistics" and other international advanced management concepts are introduced and new ways like OEM, ODM and other international trade methods appeared, which put forward higher requirements on the efficiency of the port. [5-6] The key point of technology development of improving the work efficiency of the port is the development and application of the logistics information system of the port clearance. Some port cities, such as the United States, Canada, Singapore and Europe, have adopted the international advanced customs clearance mode, with the help of electronic means, which greatly improved the efficiency of work of the port.

With the deepening of the integration of the Beijing-Tianjin-Hebei region reform, the goal of the Tianjin port is to optimize the service level. Tianjin built the convenient customs clearance environment, at the same time in the service of the open economy development of Beijing, support pinggu international land port business, thus promote the policy of dongjiang bonded port area to pinggu international land port extension; Beijing's goal is to further optimize the airport transportation logistics system, build a international platform to service Beijing-Tianjin-Hebei region, and support the regional logistics center to transfer to Tianjin. To deepen the cooperation between the three ports must speed up the flow of information between the ports, and the circulation of information resources has become the most important part of the integration of Beijing-Tianjin-Hebei port construction.
At present, the Beijing-Tianjin-Hebei port information platform is a portal which uses modern information technology, with the help of telecommunication public network resources, stores the information flow, capital flow, cargo flow of the import and export business into the port data center, using the modern information technology, with the aid of telecommunication public network resources, management state administrative organs respectively. In this unified, safe and efficient computer data platform, enterprises can achieve data sharing and data exchange, with the Internet information services. Beijing-Tianjin-Hebei port information platform mainly includes the China Electronic Port Branch, a subsidiary of Beijing Electronic Port, Tianjin electron port and the data center of the China Electronic Port Shijiazhuang sub centers, since the integration of customs clearance, Beijing, Tianjin and Hebei while carrying out electronic port cooperation, and gradually realize the port information exchange and resource sharing, and achieved satisfactory results

\section{The Operation and Information System of Logistics Information Platform of Beijing-Tianjin-Hebei Port}

Beijing, Tianjin port logistics information platform using B 2 B business model, the maturity of the profit model, including data transfer services, information dissemination, advisory services, advertising and membership. There are mainly two operation modes of the Beijing-Tianjin-Hebei port logistics information platform [7], one is port logistics information center led by the government organization, mainly co sponsored and apply for government funding to construct and operate by the relevant government departments, such as the port, the Information Committee, after the platform operate formally and get the market response, then attracting investment, and transferring this center into a limited liability company. This mode of operation is easy to get the central and local government resources, the Beijing electronic port and Shijiazhuang electronic port both use this model. The other one is port logistics information AG, such as Tianjin electronic port, which is led and established by the government.

Electronic port is the abbreviation of the law enforcement system of China's electronic port. This system uses modern information technology, with national public telecommunication network, centralize the various kinds of electronic records data of import and export business into to public data center. The state administrative department of functions can verify the cross sector and industry's Internet data, enterprises can handle various kinds of import and export business online.

The establishment of Beijing-Tianjin-Hebei electronic port benefits to strengthen the management comprehensive ability of administrative departments. Management 
department implements the new management model "Electronic + networking verification", solved the problem of the business documents fraud, crack down on smuggling, tax fraud, illegal and criminal activities, creating a fair competition market environment.

Enterprise as long as access the public telecommunications network can bid for all import and export procedures to the customs, inspection and quarantine, foreign trade, foreign exchange, industry and commerce, taxation, banking and other government authority through public data center on the Internet directly, so as to realize the government the "one-stop" service to enterprises. Enterprises through the electronic port for business, not only to save time, but also to reduce the suffering of hard work, improve trade efficiency and reduce trade costs. Therefore, the electronic port has been an important symbol of the modern trade, which is an important way to improve the transparency of administrative law enforcement, and achieve a fair, impartial, open and important way of administrative law enforcement.

\subsection{Beijing Electronic Port}

Beijing electronic port (http://www.bjeport.gov.cn/) is a comprehensive service platform, supported by 6 institution (see in Figure 1), which effectively integrates the port information resources of various local governments in Beijing City, and provides the port information for the local government of Beijing city. Beijing electronic port is also a port integrated information service and application processing platform with the characteristics of Beijing, and the service objects mainly are the enterprise, the society and the government departments.

According to the statistics of Beijing electronic port, since the reform of the integration of customs clearance in July 1, 2014 , foreign trade enterprises can free to choose the three customs clearance, customs clearance and customs clearance efficiency is also significantly improved. In 2014, the total amount of goods under customs supervision at Beijing port for 2101.7 tons, up $363.1 \%$ from a year earlier, Beijing enterprises import and export goods of $\$ 128.775$ billion through the customs declaration of the Beijing-Tianjin-Hebei region, up $8.5 \%$ from a year earlier, accounts for $31 \%$ of the whole city, the customs clearance time save $20 \%$ to $30 \%$ on average. The clearance time of the local customs clearance of Beijing enterprises decreased in 24 hours compared with the first six months in 2014. For example, Beijing enterprises import and export goods through the Tianjin port, customs clearance costs reduced by about $1 / 3$ compared with the previous reform with the condition of the same day delivery and normal clearance.

Since July 2015 to October, the average clearance time of integration of customs clearance of Beijing enterprises imports through Tianjin, Hebei Port is 51.1 hours. The clearance time for enterprises choose to declare the customs clearance in Beijing customs is 41.86 hours, and the choice in different places (Tianjin, Shijiazhuang) customs clearance is 58.36 hours, which shows that the efficiency of customs clearance for Beijing enterprises choose to declare at customs in local is significantly higher than in remote customs.

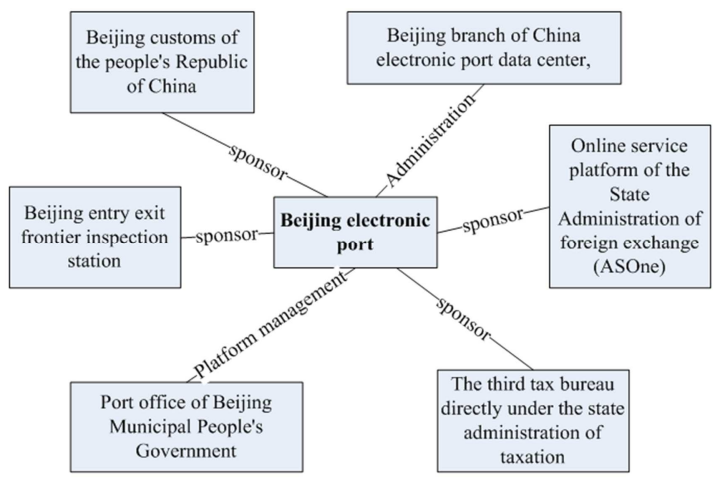

Figure 1. The construction of Beijing electronic port platform.

\subsection{Tianjin Electronic Port}

Tianjin electronic port (http://www.tjeport.gov.cn/default.htm) is built by Tianjin electronic port development co., LTD, the company is also supported by Tianjin municipal government and the General Administration of customs and other relevant ministries (see in Figure 2). Tianjin electronic port is mainly responsible for the construction and operation of the "Tianjin electronic port", constructs the whole logistics information service platform, the government law enforcement services and the entire information service platform. [8] The subordinate units of law enforcement system of Tianjin electron port site contains the Tianjin Customs, inspection and Quarantine Bureau, Tianjin Maritime Bureau, FGIS, Tianjin port and E-port.

In 2014, the total amount of the Tianjin port portal site breakthrough over 4 million, and the data exchange was up to 20.8959 million times, last year, Tianjin electronic port accepted all kinds of business consulting and solved the problem of customs clearance by "China Customs online service hall" and "12360-Customs Service Hotline" and other electronic port service functions for a total of 62548 people, average per working day about 250 passengers, which is an increase of $82 \%$, and Tianjin port has 68 online services, 89 information query function by now, gathers more than 2600 units to serve cross border e-commerce enterprises.

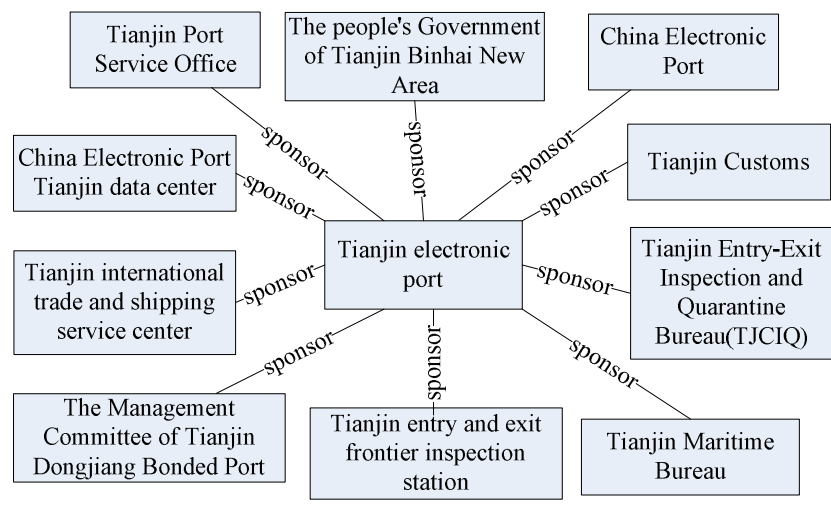

Figure 2. The construction of Tianjin electronic port platform. 


\subsection{Hebei Electronic Port}

Hebei electronic port (http://www.sjzeport.cn), also known as China electronic port center Shijiazhuang branch, has the latest version of the December 31, 2015 trial, integrates port customs clearance business consulting, data and application project content. The port this year will carry out cross-border electricity suppliers and other law enforcement services, to further improve the environment of customs clearance.

Hebei electronic port has a total of nine projects: Integrated logistics system, Electronic account system, Domestic tax collection system, Electronic tax and fee payment system, Declaration business, Electronic manual, Manifest and transport, Customs declaration, Deposit account verification network. The application center contains 2 applications and 17 integrated applications, and the establishment of the inspection unit online service, provide a single platform for foreign trade enterprises to speed up the clearance rate. [9] At present, the platform of Hebei port has over 200 thousand data records, and achieves the real-time data query of inspection and quarantine.

\section{Conclusions}

The wide application of new technologies such as cloud computing and Internet of things has become an important trend to promote the development of port information, especially the modern EDI information technology and automation technology can provide good control and management for the port logistics process. E-port on the basis of the EDI technology integrates a number of customs functions, at present, the electronic port of Beijing, Tianjin, Hebei has a dozen projects, including the networking declaration, the export tax rebate, online pay taxes, etc, mainly for foreign trade enterprises provide convenient and fast customs clearance services.

Beijing-Tianjin-Hebei electronic port based on information service platform, formed an electronic port site of its own distinguishing features, enterprises in this region are regarded as a same customs enterprise, which brought convenience for all of companies of customs clearance. Though the service function of Beijing, Tianjin and Hebei electronic port has many similar places, there are still many different places with local characteristics, Table 1, 2 is a summary of the function of three electronic ports and its website.

Table 1. The main function of portal website of Beijing-Tianjin-Hebei electronic port.

\begin{tabular}{llll}
\hline Function & Beijing & Beijing & Beijing \\
& E-port & E-port & E-port \\
\hline news information & $\sqrt{ }$ & $\sqrt{ }$ & $\sqrt{ }$ \\
Notification announcement & $\sqrt{ }$ & $\sqrt{ }$ & $\sqrt{ }$ \\
Office Guide & $\sqrt{ }$ & $\sqrt{ }$ & $\sqrt{ }$ \\
Port knowledge promotion & $\sqrt{ }$ & & \\
Data download & $\sqrt{ }$ & $\sqrt{ }$ & $\sqrt{ }$ \\
Common link & $\sqrt{ }$ & $\sqrt{ }$ & \\
Yellow Page & & $\sqrt{ }$ & \\
Government affairs public service & $\sqrt{ }$ & & \\
Administrative law enforcement system & $\sqrt{ }$ & $\sqrt{ }$ & $\sqrt{ }$ \\
\hline
\end{tabular}

Table 2. Functions of Beijing-Tianjin-Hebei electronic port.

\begin{tabular}{|c|c|c|c|c|c|}
\hline Classification & \multicolumn{5}{|l|}{ Function } \\
\hline \multirow{12}{*}{$\begin{array}{l}\text { Beijing electronic } \\
\text { port }\end{array}$} & \multirow{5}{*}{ Law Subsystem } & \multicolumn{4}{|c|}{ Inspection and clearance system } \\
\hline & & \multicolumn{4}{|c|}{ Exhibits supervision system } \\
\hline & & \multicolumn{4}{|c|}{ Import and export network audit system } \\
\hline & & \multicolumn{4}{|c|}{ Outbound pre reporting system for travel group } \\
\hline & & \multicolumn{4}{|c|}{ High risk and early warning notification system } \\
\hline & & Capital window & Inspection and quarantine & \multicolumn{2}{|l|}{ business affairs } \\
\hline & Business Function & $\begin{array}{l}\text { Foreign exchange } \\
\text { management }\end{array}$ & The tax & \multicolumn{2}{|l|}{ Tourism } \\
\hline & & Customs & Frontier inspection & \multicolumn{2}{|l|}{ The business } \\
\hline & & Trade mode & Tax or tax exemption & \multicolumn{2}{|l|}{ Application code } \\
\hline & Customs clearance & Commodity tax rate & Enterprise nature & \multicolumn{2}{|l|}{ Domestic area } \\
\hline & service function & Transport mode & Customs code & \multicolumn{2}{|l|}{ Transaction mode } \\
\hline & & Country area & Unit of measurement & Port route & \\
\hline \multirow{4}{*}{$\begin{array}{l}\text { Tianjin electronic } \\
\text { port }\end{array}$} & \multirow{3}{*}{$\begin{array}{l}\text { government law } \\
\text { enforcement services } \\
\text { logistics online service } \\
\text { The whole electronic } \\
\text { port information } \\
\text { service }\end{array}$} & Ship declaration & $\begin{array}{l}\text { The inspection and } \\
\text { quarantine manifest } \\
\text { declaration }\end{array}$ & \multirow{2}{*}{$\begin{array}{l}\text { Inspection and } \\
\text { quarantine } \\
\text { inspection } \\
\text { Yard Online }\end{array}$} & $\begin{array}{l}\text { Inspection and } \\
\text { quarantine library } \\
\text { release }\end{array}$ \\
\hline & & \multicolumn{2}{|l|}{ Cargo online } & & \\
\hline & & $\begin{array}{l}\text { Customs release } \\
\text { information inquiry }\end{array}$ & $\begin{array}{l}\text { Inspection and quarantine } \\
\text { inbound cargo release } \\
\text { information inquiry }\end{array}$ & \multicolumn{2}{|c|}{ Import manifest information query } \\
\hline & \multicolumn{5}{|c|}{$\begin{array}{l}\text { China Electronic Port Law Enforcement System } \\
\text { The trial platform } \\
\text { Network status query }\end{array}$} \\
\hline \multirow[t]{2}{*}{$\begin{array}{l}\text { Hebei electronic } \\
\text { port }\end{array}$} & \multirow{2}{*}{$\begin{array}{l}\text { Clearance information } \\
\text { inquiry }\end{array}$} & Clearance status inquiry & Customs declaration & $\begin{array}{l}\text { Commodity } \\
\text { information } \\
\text { inquiry }\end{array}$ & $\begin{array}{l}\text { Classified } \\
\text { announcement query }\end{array}$ \\
\hline & & $\begin{array}{l}\text { Manifest information } \\
\text { query }\end{array}$ & $\begin{array}{l}\text { Enterprise information } \\
\text { query }\end{array}$ & $\begin{array}{l}\text { Clearance } \\
\text { parameter query }\end{array}$ & $\begin{array}{l}\text { Inquiry of customs } \\
\text { laws and regulations }\end{array}$ \\
\hline
\end{tabular}


Though there are some progress has been made for the information construction of Beijing-Tianjin-Hebei port, some problems are still existed [10]. From the point of view of the whole country, the information level of Beijing-Tianjin-Hebei port is slower in Yangtze river delta and the pearl river delta region. And there is a lack of the mechanism of regional information sharing and coordination between ports, the first performance in the informatization level of port enterprises is generally low, and the construction focus is still concentrated in the development of basic network platform, GPS, EDI and other information technology is still in its initial stage in some of the port enterprises. Although the ports are committed to the construction of their own information database, but the information system openness is not enough. Logistics industry has no public data interface in the whole region, and the development of software systems lack of uniform standards and compatibility, which makes the port information not be shared effectively.

There are two suggestions on promoting the development of information technology in Beijing, Tianjin, Hebei port. First of all, play a fundamental role of standardization in port information management, establish a unified information data standard system with the national electronic port platform, accelerate the standardization process of electronic data interchange, and promote the standardization of the management of port, and realize the effective input of information, which can eliminate barriers to information communication between different foreign trade enterprises and promote the coordinated development of Beijing-Tianjin-Hebei port. Secondly, improve the application level of the port information, mainly based on the electronic port platform portal, and constantly improve the platform infrastructure, carry out the construction of the fourth party logistics platform. Promote the interconnection between business reporting, customs clearance management, opening of government affairs and other aspects, which can ultimately achieve the goal of the construction of the port clearance information platform.

\section{Acknowledgments}

The study is supported by Beijing Key Laboratory of
Intelligent Logistics System, (BZ 0211), and Beijing Intelligent Logistics System Collaborative Innovation Center, and the project of scientific training program for Beijing Wuzi University college students- The statistical study of basic data of the Beijing-Tianjin-Hebei logistics enterprise (2016103050).

\section{References}

[1] Yao Wen. Beijing, Tianjin and Hebei reached 10 consensus to promote market integration $[\mathrm{N}]$. China International Business, 2015-12-01 A 03.

[2] Jiao Lili, Zhang Dan. Beijing-Tianjin-Hebei port from competition to coopetition [J]. Practice in Foreign Economic Relations and Trade, 2015, 01: 78-81.

[3] Zhao Wei. Integration of Beijing-Tianjin-Hebei region is helpful to Play port advantages for Tianjin airport [N]. China Civil Aviation News, 2015-05-29001.

[4] Deng Shaoling. Port logistics information platform [M]. China Communications Press, 2007.

[5] Garstone S. Electronic data interchange (EDI) in port operations [J]. Logistics Information Management, 1989, 8 (4): 30-33.

[6] Kia M, Shayan E, Ghotb F. The Important of Information Technology in Port Terminal Operations [J]. International Journal of Physical Distribution \& Logistics Management, 2000, 30 (3/4): 331-344.

[7] Li Yuanai. Demand and Development Countermeasures of Information Service among Medium and Small Sized Logistics Enterprises in China [J]. Logistics Engineering and Management, 2015, 37 (1): 70-72.

[8] Tianjin port serves the coordinated development of Beijing-Tianjin-Hebei [J]. The People's Congress of Tianjin, 2014, 05: 18 .

[9] Zhang Dongmei, Shijiazhuang inland port construction boost development of the integration of Beijing-Tianjin-Hebei [J]. Hebei Enterprises, 2015, 12: 72-73.

[10] Liu Guanghua, Mu Yingai, ZhaoYu, et al. Research on the strategy of promoting the integrated development of Beijing-Tianjin-Hebei Port [J]. Economic Forum, 2015, 10: $10-12$. 